\title{
$\mathrm{NbCl}_{5}-\mathrm{SnCl}_{2}-\mathrm{EMIC}$ 系常温型溶融塩浴からの $\mathrm{Nb}_{3} \mathrm{Sn}$ 超伝導合金の電析
}

\author{
小浦延幸*，芝野憲司*，松本 太*，松澤秀則**，加藤智紀*，井手本 康*，凌 国平*** \\ *東京理科大学 理工学部（干278-8510 千葉県野田市山崎 2641） \\ **千葉工業大学（干275-0023 千葉県習志野市芝園 2-1-1） \\ ***浙江大学（中華人民共和国浙江省杭州市）
}

\section{Electrodeposition of $\mathrm{Nb}_{3} \mathrm{Sn}$ Alloy Superconductor from $\mathrm{NbCl}_{5}-\mathrm{SnCl}_{2}-\mathbf{E M I C}$ Room Temperature Molten Salt}

\author{
Nobuyuki KOURA*, Kenji SHIBANO*, Futoshi MATSUMOTO*, Hidenori MATSUZAWA** \\ Tomonori KATOU*, Yasushi IDEMOTO* and Guoping LING***

\begin{abstract}
${ }^{*}$ Faculty of Science and Engineering, Tokyo University of Science (2641, Yamazaki, Noda-shi, Chiba 278-8510) ** Department of Chemistry, Chiba Institute of Technology (2-1-1, Shibazono, Narashino-shi, Chiba 275-0023) ${ }^{* * *}$ Department of Material Science \& Engineering, Zhejiang University (Hangzhou, 310027, P.R.China)
\end{abstract}

Key Words : Room Temperature Molten Salt, $\mathrm{Nb}_{3} \mathrm{Sn}$ Superconductor, 1-ethyl-3-methylimidazdium Cholride

\section{1. 緒言}

超伝導現象の応用は，高エネルギー粒子加速器，エネルギー貯 蔵などの超大型の機器から, 最近, 身近な応用として超伝導マグ ネットを用いたリニアモーターカー，医療診断用核磁気共鳴映像 装置などさまざまな分野で脚光を浴びている。このように超伝導 の応用が多様化するにしたがい, 安全でより高い性能を持つ超伝 導体の開発およびその使用が要求されてきている。 $\mathrm{Nb}_{3} \mathrm{Sn}^{11}$ は, 超伝導特性としての臨界温度, 臨界磁場, 臨界電流密度, 特に 9 $\mathrm{T}$ 以上の高磁界側での特性が優れている有用な超伝導体である。 しかし，金属間化合物であるため極めて脆い性質を有することか ら, その製作には複合加工法 ${ }^{2)}$ な゙の複雑な工程が必要である。 この $\mathrm{Nb}_{3} \mathrm{Sn}$ を電析により得ることができれば，電極の形状を変 えることにより，さまざまな形状の超伝導体を，単一行程かつ連 続的に作製することが可能となる。我々は，これまで発火や引火 の危険性が無い 1 -エチル-3-メナルイミダゾリウムクロリド (EMIC) を用いた常温型溶融塩浴から, 電析によって $\mathrm{Nb}_{3} \mathrm{Sn}$ 超 伝導体を得ることを目的とし，電析条件の確立を行ってきており， $2.8 \mathrm{~mol} \% \mathrm{SnCl}_{2}-68.6 \mathrm{~mol}_{0} \mathrm{NbCl}_{5}-28.6 \mathrm{~mol} \% \mathrm{EMIC}$ 浴におい て, パルス周期 $0.1 \mathrm{~s}$, パルスデューティー比 0.2 , パルス電流 密度 $1.5 \times 10^{3} \sim 2.0 \times 10^{3} \mathrm{~A} \cdot \mathrm{m}^{-2}$, 浴温 $433 \mathrm{~K}$, 電気量 $50 \mathrm{C}$ で電 析を行った時, 電析物の $\mathrm{Nb}$ 含有率が $64.7 \mathrm{wt} \%$ の值を示す結果 を得ている3)。この值は, $\mathrm{Nb}_{3} \mathrm{Sn}$ の $\mathrm{Nb}$ 含有率 $70.1 \mathrm{wt} \%$ に近い 值であるが，電析物は超伝導特性を示さなかった。そこで本研究 では，パルス周期，パルス電流密度などの条件を変化させること により， $\mathrm{Nb}$ 含有率の向上を検討し，得られた電析物の評価を 行った。

\section{2. 実験方法}

溶融塩の調製に用いた $\mathrm{SnCl}_{2}, \mathrm{NbCl}_{5}$ は，和光純薬製特級試薬
を十分に乾燥させてから用いた。EMIC は, 文献(4)にしたがい 合成した。 $\mathrm{SnCl}_{2}-\mathrm{NbCl}_{5}$-EMIC 系溶融塩は, $403 \mathrm{~K}$ の条件にお いて所定量の $\mathrm{EMIC} と \mathrm{SnCl}_{2}$ を混合して溶融させ, 続いて $\mathrm{NbCl}_{5}$ を少量ずつ添加することにより三元系浴を調製した。そ の後, 浴の精製のために $99.99 \% \mathrm{Sn}$ 板を 24 時間浴に浸漬した。 電析は, 銅の基材 $(99.99 \%)$ 上にパルス周期 $0.01 \mathrm{~s}$ ，パルス デューティー比 0.2 , 浴温 $433 \mathrm{~K}$, 電気量 $50 \mathrm{C}$ の条件において, パルス電流密度 $\left(1.5 \times 10^{3} \sim 5.0 \times 10^{3} \mathrm{~A} \cdot \mathrm{m}^{-2}\right)$ を変化させること により検討を行った。これらの操作はすべて乾燥 $\mathrm{Ar}$ 雾囲気グ ローブボックス中において行った。得られた電析物の分析は, ICP 発光分光分析法 (Leemanlab 製 PS series ICP/Echelle Spectrometer)を用いてその組成の評価を，X 線回折測定によ り相の同定を行った。作製した電析物の超伝導特性は, 直流四端 子法による抵抗率測定により確認した。今回の実験においては, 電析薄膜のみを電極基材から剝がすことが困難であったため, 電 極基材上の薄膜について抵抗率測定を行った。

\section{3. 実験結果および考察}

図 1 に電流密度 $\left(1.0 \times 10^{3} \sim 5.0 \times 10^{3} \mathrm{~A} \cdot \mathrm{m}^{-2}\right)$ と電析物中の $\mathrm{Nb}$ 含有率の関係を示す。 $1.0 \times 10^{3} \sim 4.0 \times 10^{3} \mathrm{~A} \cdot \mathrm{m}^{-2}$ において, 電流密度が増加するにしたがい $\mathrm{Nb}$ 含有率が増加し, $4.0 \times 10^{3}$ $\mathrm{A} \cdot \mathrm{m}^{-2}$ において最も大きな值 $68.8 \mathrm{wt} \%$ を示した。次に $1.0 \times$ $10^{3}$ および $4.0 \times 10^{3} \mathrm{~A} \cdot \mathrm{m}^{-2}$ の条件において得られた電析物の $\mathrm{X}$ 線回折測定 (図 2 )を行った。電流密度 $4.0 \times 10^{3} \mathrm{~A} \cdot \mathrm{m}^{-2}$ の場合, 基材の $\mathrm{Cu}$ と $\mathrm{Nb}_{3} \mathrm{Sn}^{5}$ のピークのみが現れた。一方, $\mathrm{Nb}$ 含有率

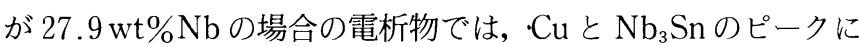
加えて Sn 単体のピークも出現しており, 電析物に $\mathrm{Nb}_{3} \mathrm{Sn}$ の析 出部分と Sn 単体の析出部分があると考えられる。また， $4.0 \times$ $10^{3} \mathrm{~A} \cdot \mathrm{m}^{-2}$ の条件で得られた電析物表面の SEM 写真を図 2 - (c) 


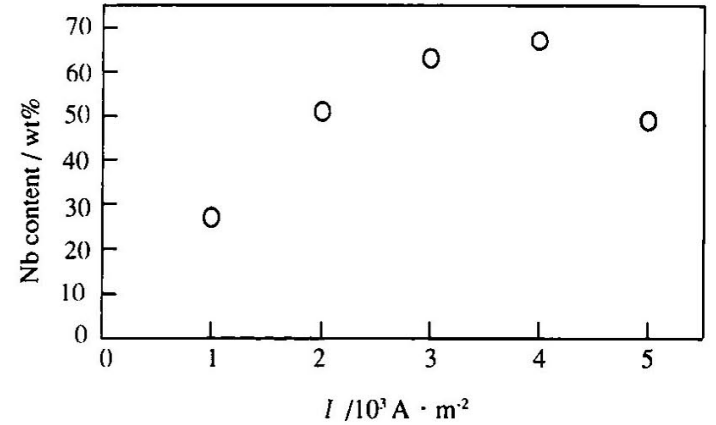

Fig. 1 Relationship between current density and $\mathrm{Nb}$ content in the deposits obtained in the pulse electrolysis (duty ratio: 0.2 , pulse period: $0.01 \mathrm{~s}$, bath temperature: $433 \mathrm{~K}$ ) from $2.8 \mathrm{~mol} \% \mathrm{SnCl}_{2}-68.6 \mathrm{~mol} \% \mathrm{NbCl}_{5}-28.6$ mol\% EMIC molten salt.
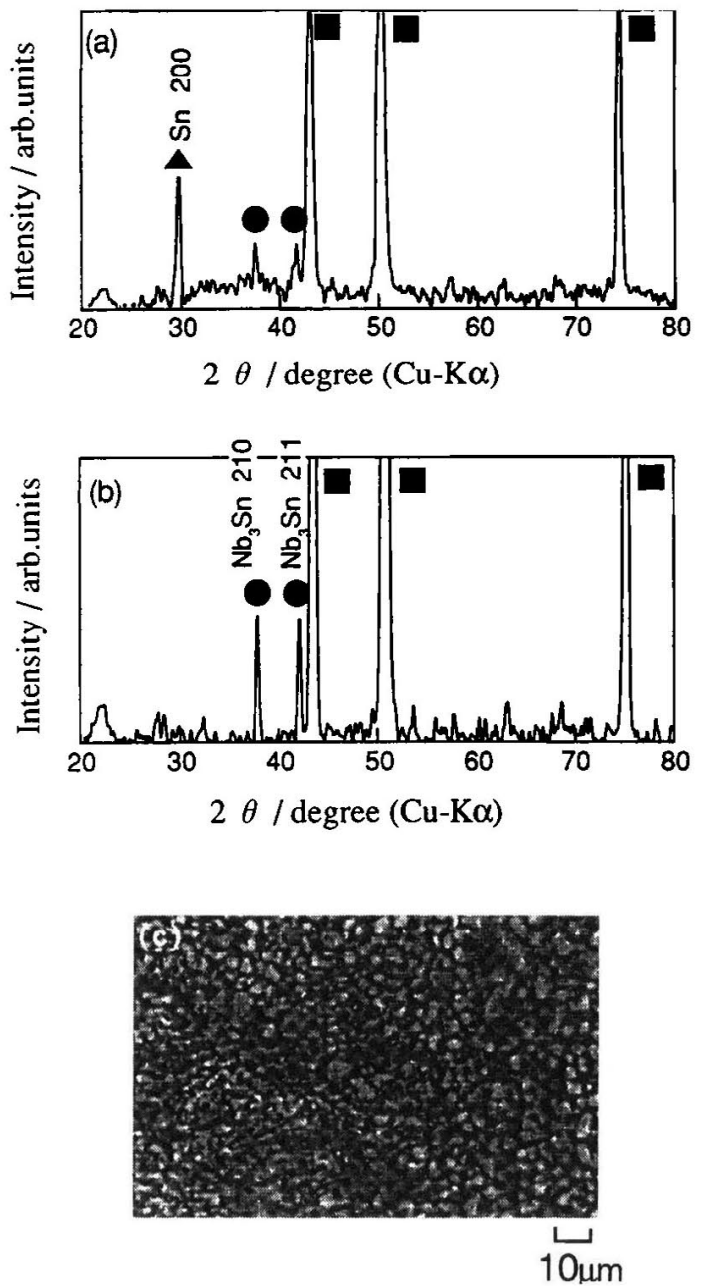

Fig. 2 XRD diffraction patterns of deposits obtained in the pulse electrolysis (duty ratio: 0.2 , pulse period : 0.01 $\mathrm{s}$, bath temperature : $433 \mathrm{~K}$ ) from $2.8 \mathrm{~mol}^{\circ} \mathrm{SnCl}_{2}-$ $68.6 \mathrm{~mol} \% \mathrm{NbCl}_{5}-28.6 \mathrm{~mol} \%$ EMIC molten salt. Current density, (a) : $1.0 \times 10^{3}$, (b) $: 4.0 \times 10^{3} \mathrm{~A} \cdot \mathrm{m}^{-2}$, : $\mathrm{Nb}_{3} \mathrm{Sn}, \mathbf{\square}: \mathrm{Cu}, \boldsymbol{\Delta}: \mathrm{Sn}$. (c) : Surface morphology of the deposit (b).

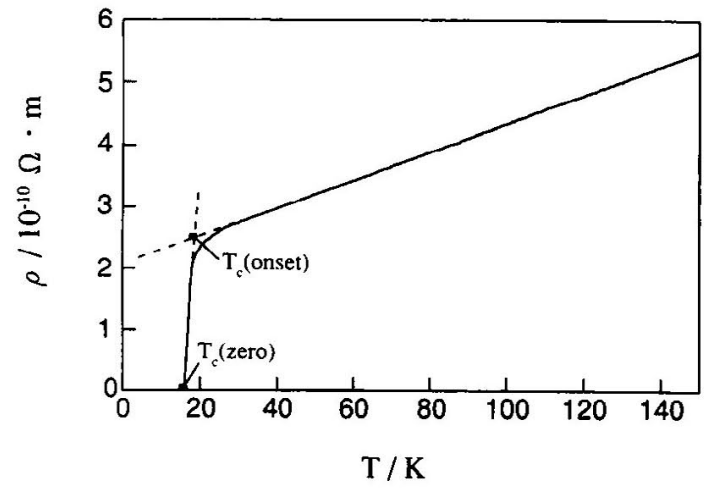

Fig. 3 Resistivity vs. temperature curve of the deposit obtained in the pulse electrolysis (duty ratio: 0.2 , pulse period $: 0.01 \mathrm{~s}$, bath temperature $: 433 \mathrm{~K}$, current density $: 4.0 \times 10^{3} \mathrm{~A} \cdot \mathrm{m}^{-2}$ ) from $2.8 \mathrm{~mol}^{\circ} \mathrm{SnCl}_{2}-68.6$ mol\% $\mathrm{NbCl}_{5}-28.6 \mathrm{~mol} \%$ EMIC molten salt.

に示す。その表面は，2 $2 \times 10^{-6} \mathrm{~m}$ 程度の凹凸により形成さ れ、クラックなどは観察されなかった。また, SEM による断面 観察から膜厚は， $1.0 \times 10^{-5} \mathrm{~m}$ であった。さらに，Nb含有率 $68.8 \mathrm{wt} \%$ の電析物を熱処理などを行わず，そのまま抵抗率測定 を行ったところ, 図 3 に示すように超伝導特性を示す結果を得た。 得られた物質は $\mathrm{Tc}$ (onset) $=19 \mathrm{~K}, \mathrm{Tc}$ (zero) $=16 \mathrm{~K}$ を示した。 したがって， $\mathrm{Nb}_{3} \mathrm{Sn}$ 超伝導体が，2.8 mol\% $\mathrm{SnCl}_{2}-68.6 \mathrm{~mol} \%$ $\mathrm{NbCl}_{5}-28.6 \mathrm{~mol} \% \mathrm{EMIC}$ 常温型溶融塩からの電析による単一行 程で作製できたと判断した。しかし，通常，金属系の超伝導体は Tc (onset) と Tc (zero)の差がほとんど無いが, 本研究で得られ た電析物では， $3 \mathrm{~K}$ の差が観察された。この原因としては，基 板に用いた良伝導体である $\mathrm{Cu}$ の影響, 超伝導体の体積分率が少 ない，あるいは結晶性も含め完全に均質な超伝導体になっていな いなどの原因が考えられる。本実験結果を踏まえ，電析物の熱処 理を行う必要があると考えられ，現在検討中である。

\section{4. 結 論}

$\mathrm{SnCl}_{2}-\mathrm{NbCl}_{5}-\mathrm{EMIC}$ 系常温型溶融塩からの電析を検討し，パ ルス周期 $0.01 \mathrm{~s}$, パルスデューティー比 0.2 , 電流密度 $4.0 \times 10^{3}$ $\mathrm{A} \cdot \mathrm{m}^{-2}$, 浴温 $433 \mathrm{~K}$, 電気量 $50 \mathrm{C}$ の条件において, 膜厚 $1.0 \times$ $10^{-5} \mathrm{~m}$ の $\mathrm{Nb}_{3} \mathrm{Sn}$ の超伝導薄膜が電析により得られたことを, $\mathrm{X}$ 線回折測定および電析物の抵抗率測定を行うことにより明らかに した。

(Received June 4, 2001 ; Accepted July 13, 2001)

\section{文献}

1) M. Suenaga, W. B. Sampson ; Appl. Phys. Lett., 20 (11), 443 (1972)

2 ) 田中靖三；超伝導とその応用, p. 57 (産業図書, 1989)

3 ) N. Koura, T. Umebayashi, Y. Idemoto, G. Ling : Electrochemistry, 67(6), 684 (1999)

4) J. S. Wilkes, J. A. Levisky, R. A. Wilson, C. L. Hussey ; Inorg. Chem., 21, 1263 (1982)

5 ) T. Nasu, Y.S. Cho, R. A. Naslund, P. L. Jones, A. L. Greer ; J. Non-Crystalline Solids, 232-234, 594 (1998) 